\title{
Autophagy in cancer
}

\section{Xiaoyong Zhi ${ }^{1}$ and Qing Zhong ${ }^{2 *}$}

\author{
Addresses: ${ }^{1}$ Center for Autophagy Research, Department of Internal Medicine, University of Texas Southwestern Medical Center, Dallas, \\ Texas 75390, USA; ${ }^{2}$ Department of Biochemistry, University of Texas Southwestern Medical Center, Dallas, Texas 75390, USA \\ *Corresponding author: Qing Zhong (Qing.Zhong@UTSouthwestern.edu) \\ Fl000Prime Reports 2015, 7:18 (doi:10.12703/P7-18) \\ All FI000Prime Reports articles are distributed under the terms of the Creative Commons Attribution-Non Commercial License \\ (http://creativecommons.org/licenses/by-nc/3.0/legalcode), which permits non-commercial use, distribution, and reproduction in any medium, \\ provided the original work is properly cited. \\ The electronic version of this article is the complete one and can be found at: http://fl $000 . c o m / p r i m e / r e p o r t s / b / 7 / / 8$
}

\begin{abstract}
Autophagy is a catabolic degradation process in which cellular proteins and organelles are engulfed by double-membrane autophagosomes and degraded in lysosomes. Autophagy has emerged as a critical pathway in tumor development and cancer therapy, although its precise function remains a conundrum. The current consensus is that autophagy has a dual role in cancer. On the one hand, autophagy functions as a tumor suppressor mechanism by preventing the accumulation of damaged organelles and aggregated proteins. On the other hand, autophagy is a key cell survival mechanism for established tumors; therefore autophagy inhibition suppresses tumor progression. Here, we summarize recent progress on the role of autophagy in tumorigenesis and cancer therapy.
\end{abstract}

\section{Introduction}

Cancer cells are like the spoiled siblings of normal cells, running rampant with unrestricted growth. To deal with them, it is important to understand two questions: what serves as a critical barrier to prevent normal cells from turning into cancer cells and what provides the crucial (and addictive) support for cancer cells allowing them to maintain their high demand for metabolism and growth? Current studies suggest autophagy as one solution to both of these questions. In this review, we summarize results from recent autophagy studies about the mutational landscape of autophagy genes in human cancers, the mouse genetic evidence for the roles of autophagy in tumor promotion or inhibition, current anti-autophagy drugs in clinical trials for cancer treatment, and future directions in cancer therapy targeting autophagy.

\section{Are autophagy genes mutated or altered in human cancers?}

Autophagy is first linked to human cancer through the identification of Beclin 1 (BECN1 hereafter, italic for the gene, nonitalic for the protein), an autophagy essential gene, as a haploid-insufficient tumor suppressor $[1,2]$. The BECN1 gene has been mapped to a tumorsusceptibility locus on human chromosome 17q21 that is monoallelically deleted in up to $40-75 \%$ of ovarian cancers, breast cancers, and prostate cancers $[1,2]$, raising the possibility that it may be a tumor suppressor. However, in the deleted chromosome region, BECN1 is adjacent to BRCA1 (breast cancer 1, early onset), which is a breast cancer tumor suppressor gene frequently mutated in familial breast and ovarian cancers. It has recently been argued that BECN1 is likely a "passenger" which is coincidently deleted with BRCA1, rather than the deletion itself being a cause of breast or ovarian cancers [3], because the statistical analysis of the mutation profiles of BRCA1 and BECN1 in breast and ovarian cancers from The Cancer Genome Atlas (TCGA) showed that large deletions in human breast and ovarian cancers often encompass both BRCA1 and BECN1 (the majority), or $B R C A 1$ alone (a small proportion), but rarely BECN1 alone [3].

Interestingly, BRCA1 is not a haploid-insufficient tumor suppressor gene; therefore monoallelic deletion may not affect its function or affect tumorigenesis of those breast cancers bearing deletions. BRCA1 is a classical tumor suppressor and it is inactivated only when both gene copies/alleles are mutated (one by germ-line mutation and the other by somatic mutation). Together, BRCA1 
and BRCA2 germ-line mutations account for about $20-25 \%$ of hereditary breast cancers, while they rarely occur in sporadic breast cancers $[4,5]$. Mouse genetic studies indicated that one copy of BRCA1 is sufficient to maintain its tumor suppressor function. About ten different conventional BRCA1 mouse mutants have been generated, each carrying a mutation in different regions of the gene. None of the heterozygous BRCA1 mouse mutants developed spontaneous cancers [6].

In contrast, mouse genetic studies showed that one copy of BECN1 is insufficient to support its full function in autophagy (haploinsufficiency), which therefore may cause harmful effects and promote tumorigenesis. Unlike $B R C A 1$, heterozygous disruption of BECN1 in mice increased the frequency of spontaneous malignancies, although over a long latent period (13-18 months) [7,8]. These observations support the notion that BECN1 is a haploid-insufficient tumor suppressor gene and distinguish it from other classic tumor suppressors that require both alleles be inactivated in promoting tumorigenesis. The haploid-insufficient properties of BECN1 correlate well with the frequent monoallelic deletion of the BECN1 containing region in breast and ovarian cancers, suggesting a critical role of BECN1 and likely autophagy in tumor suppression. If combining BECN1 monoallelic deletion with other cancer promoting models, BECN1 monoallelic deletion has a mixed effect in different cancer models (Table 1). More studies are needed in order to understand its function in tumorigenesis thoroughly.

While a large body of studies is focused on the BECN1 gene relevance to human cancers, a number of studies showed that other ATG genes are also oncogenically associated [9]. Single amino acid mutations in mTOR are found in several types of human cancers, which confer constitutive activation of this autophagy negative regulator $[10,11]$. Somatic point mutations of ATG5 are also identified in 135 patient samples of gastric cancer, colorectal cancer, and hepatocellular carcinoma, which are associated with decreased cellular expression of ATG5 protein [12]. Furthermore, frameshift mutations have been found in ATG2B, ATG5, and ATG9B (alone or in combination) in gastric cancer and colorectal cancer samples [13]. Given the number of identified autophagy genes in humans (over 30), more extensive genome sequencing efforts should be targeted towards autophagy genes in cancer patients. In this way, the mutational landscape of autophagy genes in human cancers can be more precisely defined.

Table I. Tumorigenesis in autophagy deficient mouse models

\begin{tabular}{|c|c|c|}
\hline Autophagy deficient mouse models & Tumorigenic consequences & Ref. \\
\hline $\mathrm{BECN} I^{+/-}$ & $\begin{array}{l}\text { Increased spontaneous tumorigenesis; accelerated development of HBV-induced } \\
\text { premalignant lesions; mammary gland and splenic germinal center hyperplasia. }\end{array}$ & [7] \\
\hline $\mathrm{BECNI}{ }^{+/-}$ & Increased cancer rate. & [8] \\
\hline BECNI ${ }^{+/}$, Palb2 $2^{\text {flox } / \text { flox }}$, WAP-Cre, $p 53^{+/+}$or $p 53^{\text {flox/flox }}$ & Reduced Palb2-associated mammary tumorigenesis in a $p 53$ dependent manner. & [79] \\
\hline $\mathrm{BECNI}{ }^{+/-}, \mathrm{Atm}^{--}$ & Delayed lymphoma development. & [80] \\
\hline$B E C N I^{+\infty}, E \mu-m y c$ & Accelerated onset of B-cell lymphoma. & [80] \\
\hline$B E C N I^{+1-}$, MMTV-Erbb2 & No impact on Erbb2-driven mammary tumorigenesis. & [8I] \\
\hline$B E C N I^{+1-}$, MMTV-PyMT & No impact on PyMT-driven mammary tumorigenesis. & [81] \\
\hline Bifl $^{-1-}$ & Increased spontaneous lymphomagenesis. & [82] \\
\hline Bifl $^{+/}$, Eu-myc & Accelerated onset of B-cell lymphoma. & [83] \\
\hline FIP200 flox/fox, MMTV-Cre, MMTV-PyMT & Suppressed PyMT-driven mammary tumor initiation and progression. & [25] \\
\hline $\operatorname{Atg} 4 C^{-1-}$ & Increased susceptibility to chemical carcinogen induced fibrosarcomas. & [84] \\
\hline 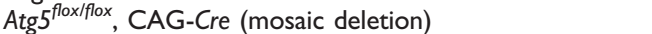 & Carry multiple liver tumors. & [18] \\
\hline Atg5 $5^{\text {flox/flox }}$, Adeno-Cre, LSL-Kras GI2D,$p 53^{+/+}$or $p 53^{\text {flox/flox }}$ & $\begin{array}{l}\text { Impaired progression, but accelerated onset of } \mathrm{Kras}^{\mathrm{GI}}{ }^{2 \mathrm{D}} \text {-driven lung cancer in a } \\
\mathrm{p} 53 \text { dependent manner. }\end{array}$ & [20] \\
\hline Atg $5^{\text {flox/flox }}$, PdxI-Cre, LSL-Kras ${ }^{G 12 D}$ & $\begin{array}{l}\text { Enhanced Kras }{ }^{G 12 D} \text {-driven PanIN formation and blocked progression of } \\
\text { Kras }{ }^{G / 2 D} \text {-driven low grade PanIN to high grade PanIN and PDAC. }\end{array}$ & [19] \\
\hline $\operatorname{Atg} 5^{f l o x / f l o x}$, PdxI-Cre, LSL-Kras ${ }^{G \mid 2 D}, p 53^{f l o x /+}$ & $\begin{array}{l}\text { Increased PanIN formation and inhibited progression of } K \text { ras }{ }^{12 D} \text {-driven low } \\
\text { grade PanIN to high grade PanIN and PDAC, regardless of p } 53 \text { status. }\end{array}$ & [34] \\
\hline Atg $7^{\text {flox/flox }}$, Alb-Cre & Develop liver tumors. & [18] \\
\hline Atg $7^{\text {flox/flox }}, \mathrm{PdxI}-\mathrm{Cre}, \mathrm{LSL}-\mathrm{Kras}^{\mathrm{GI} \text { 2D }}, \mathrm{p} 53^{+/+}$or $p 53^{\text {flox } / f l o x}$ & $\begin{array}{l}\text { Enhanced Kras }{ }^{G / 2 D} \text {-driven PanIN formation, which is accelerated by loss of } p 53 \text {; } \\
\text { blocked progression of Kras }{ }^{G \mid 2 D} \text {-driven low grade PanIN to high grade PanIN and } \\
\text { PDAC, which is diminished by loss of } p 53 \text {. }\end{array}$ & [19] \\
\hline Atg $7^{\text {flox/flox }}$, Adeno-Cre, LSL-Kras ${ }^{G \mid 2 D}, p 53^{+/+}$or $p 53^{\text {flox/flox }}$ & $\begin{array}{l}\text { Reduced Kras }{ }^{G / 2 D} \text {-driven lung tumor burden and altered tumor fate from } \\
\text { adenoma and carcinoma to oncocytoma in both } p 53 \mathrm{WT} \text { and null mice. }\end{array}$ & [23] \\
\hline Atg $7^{\text {flox/flox }}$, Adeno-Cre, LSL-Braf ${ }^{1600 E}, p 53^{+/+}$or $p 53^{\text {flox/flox }}$ & $\begin{array}{l}\text { Robust early onset of Braf }{ }^{\mathrm{V} 600 \mathrm{E}} \text {-driven lung cancer and altered tumor progression } \\
\text { from adenoma and carcinoma to oncocytoma in both } p 53 \mathrm{WT} \text { and null mice. }\end{array}$ & [24] \\
\hline $\begin{array}{l}\text { Atg } 7^{\text {flox/flox }} \text {, Ubc-CreERT2, Adeno-FLPo, Kras }{ }^{G \mid 2 D-f r t /+} \text {, } \\
\text { p53 } 3^{\text {frttfrt (acute deletion) }}\end{array}$ & No effect on lung tumor initiation; impaired lung tumorigenesis over time. & [17] \\
\hline
\end{tabular}

Abbreviations: ATM, ataxia-telangiectasia mutated; WT, wild type; PALB2, partner and localizer of BRCA2; ERBB2, v-erb-b2 avian erythoblastic leukemia viral oncogene homolog 2; PyMT, polyoma middle T; PanIN, pancreatic intraepithelial neoplasia; PDAC, pancreatic ductal adenocarcinoma. 


\section{Does autophagy suppress tumorigenesis?}

If autophagy plays an important role in tumor suppression, as suggested in BECN1 heterozygous mutant mice, one would expect other autophagy essential genes would also have a function in tumor suppression. This seemingly straightforward statement is brought into question by the absolute requirement of autophagy genes in embryonic, neonatal and adult development. Homozygous deletion of $B E C N 1$ leads to embryonic lethality [14]. Atg5 and Atg7 null mutants died right after birth $[15,16]$. Inducible knockout of Atg7 in adult mice (8-10 weeks) killed the animals within 3-7 months with hyperglycemia and neurodegeneration [17]. The acute lethality of autophagydeficient mice compromises their use in studying tumorigenesis, as that probably requires a longer time window.

Mizushima's group found their Atg $5^{\text {flox/flox; }}$ CAG-Cre mutant mice displayed a mosaic phenotype for an unknown reason even with the ubiquitous expression of the Cre recombinase [18]. Although, in most cases, $60-90 \%$ of cells in various organs of Atg $5^{f l o x} / f l o x$; CAG-Cr are Atg5 null, it appears that the remaining $\operatorname{Atg} 5$ is enough to execute the minimum function of autophagy. Consequently, Atg5 flox/flox; CAG-Cre mice were viable and can survive more than 19 months. This mosaic Atg5 mutant mouse strain allows researchers to study the contribution of Atg5 to tumorigenesis. Premalignant liver tumors were detected in all 17 Atg $5^{\text {flox/flox; }}$ CAG-Cre mice after 9 months [18]. Consistently, premalignant live tumors were also observed in liver-specific ATG7deficient mice with nearly $100 \%$ penetrance after 12 months [18]. Although no malignant cancer was detected in this setting, the high penetrance to premalignant tumor suggests that autophagy likely functions as a tumor suppression mechanism. It is currently unknown why autophagy deficiency can only lead to premalignant tumors but not malignant cancers, which are often more invasive and metastatic. It is not clear, at least from these studies, if these premalignant tumors in autophagy-deficient mice are in a "benign" state that requires additional genetic alterations to promote malignant transformation (e.g. p53 mutation), or if autophagy inhibition can only promote premalignant/ benign tumor formation but somehow protects cells from advancing to malignant cancers (Figure 1). It is also possible that the premalignant tumor formation is secondary to other cancer prone responses, like inflammation caused by autophagy deficiency.

Several factors have been suggested as candidates for blocking autophagy-deficient animals from developing malignant cancer. Ryan's group proposed that growth arrest, senescence, and cell death mediated by p53 might act as barriers to the progression of premalignant cancer lesions to malignant cancer in a humanized geneticallymodified mouse model of pancreatic ductal adenocarcinoma (PDAC) [19]. They showed that mice null for Atg7 or Atg5, but not wild-type mice, prevent progression to malignant PDAC driven by $\mathrm{Kras}^{\mathrm{G} 12 \mathrm{D}}$ [19]. However, if p53 is concomitantly deleted from the mouse genome, Atg7 deletion accelerates rather than inhibits progression to PDAC [19], probably because autophagy loss increases glucose uptake. This study raised an interesting point, at least in the $\mathrm{Kras}^{\mathrm{G} 12 \mathrm{D}}$-driven PDAC mouse model: malignant tumor development is highly dependent on autophagy and p53 status. In addition to these studies, evidence supporting the role of autophagy in tumor suppression is summarized in Table 1.

\section{Does autophagy inhibition suppress tumorigenesis?}

The current consensus is that autophagy has a dual role in cancer (Figure 1) [20]. In normal cells, autophagy functions as a surveillance mechanism to remove damaged organelles and aggregated proteins. In doing so, autophagy reduces DNA damage, reactive oxygen species (ROS), and mitochondrial abnormality, which likely protects normal cells from transforming to tumor cells. On the other hand, in established tumor cells, autophagy is hijacked to serve as a cell survival mechanism that plays a vital role in facilitating tumor cell growth. Several potential mechanisms have been suggested: autophagy promotes metabolite turnover and absorption in tumor cells to meet their high demand of metabolism and growth; autophagy inhibits apoptosis caused by mitochondrial malfunctions and ROS production; or autophagy increases drug resistance [21]. Of note, certain types of cancer cell, including pancreatic and lung cancer cells, are heavily reliant on growth benefits brought by autophagy activation, therefore becoming "addicted" to autophagy. Inhibition of autophagy in these autophagy "addicted" cancer cells might remarkably change the "life and death" balance of tumor cells and consequently suppresses tumorigenesis [22]. In the $\mathrm{Kras}^{\mathrm{G} 12 \mathrm{D}}$ and $\mathrm{Braf} \mathrm{f}^{\mathrm{V} 600 \mathrm{E}}$-driven lung cancer models, autophagy ablation altered the tumor fate from adenoma and carcinoma (malignant) to oncocytoma (benign) [23,24], indicating that autophagy inhibition promotes the regression of malignant tumors to benign tumors (Figure 1). The underlying mechanism of this transition is not entirely understood. Possibly, autophagy maintains the survival of malignant tumor cells by removing defective mitochondria and reducing ROS. Autophagy inhibition removes this protection and exposes malignant tumor cells to ROS cytotoxicity [24].

In a recent study, White's group utilized a novel strategy to dissect the function of autophagy in tumorigenesis 
Figure I. The proposed roles of autophagy in tumorigenesis

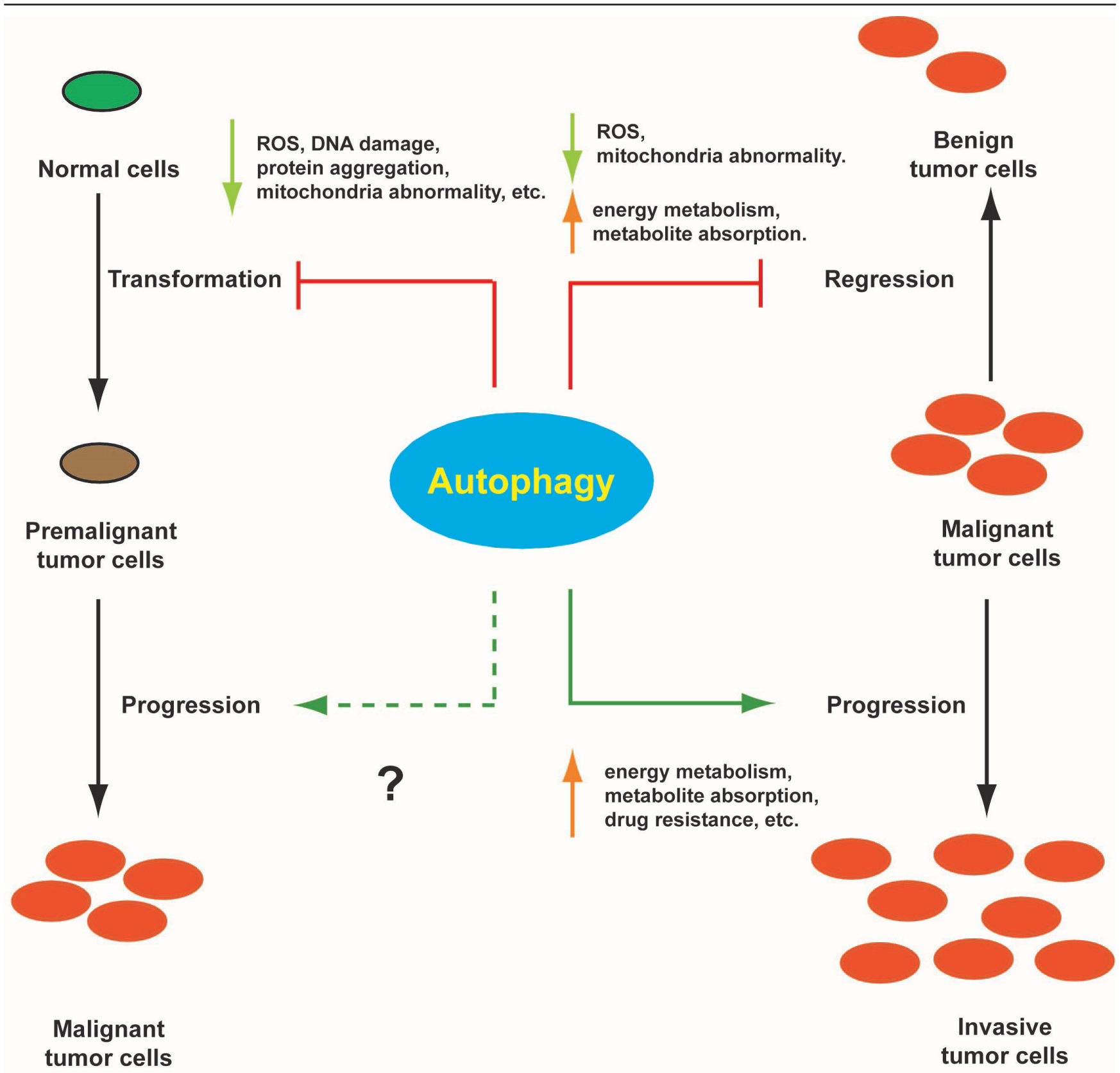

In normal cells, autophagy inhibits their transformation to premalignant tumor cells by reducing reactive oxygen species (ROS), DNA damage, protein aggregation, and mitochondrial abnormality etc. In established tumor cells, autophagy promotes their growth by serving as a cell survival mechanism. Recent evidence indicates that autophagy inhibits the regression of malignant tumor cells to benign tumors. It has yet to be determined if autophagy promotes the progression of premalignant tumor cells to malignant tumor cells.

globally rather than in a tissue-specific manner [17]. This strategy was used to bypass the requirement of autophagy to embryogenesis: Atg7 was inducibly deleted from 8-10 weeks adult mice with floxed alleles of Atg7. The expression of the Cre recombinase in this study is under the control of a ubiquitously expressed promoter that leads to a nearly complete and sustained loss of Atg7 protein in all examined tissues (different from the mosaic Atg5 KO mice from Mizushima's lab as we discussed above). A week after Atg7 was deleted; lung 
tumorigenesis was initiated by Kras activation and p53 depletion by adenoviral expression of the Flp recombinase. Three weeks later, there was no detectable difference in tumor frequency or burden between Atg7intact or Atg7-deleted mice, suggesting that autophagy may not be required for tumor initiation in this case. However, this experimental condition is clearly different from the experiment using the Atg5 mosaic mutant mice described by Mizushima's group [18]. In such a short period after Atg7 deletion (4 weeks), it is unlikely that premalignant or benign tumors can form (it takes 9 months for the Atg5 mosaic mutant mice to develop premalignant liver tumors [18]) to prime malignant progression. Nevertheless, at least in this experimental setting, loss of autophagy seems to have no dramatic effect in an acute tumorigenesis mouse model.

On the other hand, White's group observed a very robust effect of autophagy ablation in reversing malignant cancers to benign tumors: in a converse experiment, lung tumors were generated before inducible Atg7 deletion, after only 5 weeks, both tumor size and burden were significantly reduced [24]. These observations are consistent with a previous report from the same group showing that lung-specific deletion of Atg7, concurrently with tumor initiation by Kras activation and p53 deletion, also reduces tumor burden and generates benign oncocytomas [23]. In addition, deletion of FIP200 suppressed PyMT-driven mammary tumor initiation and progression, which represents another example of an autophagy gene that, when deleted, impairs tumorigenesis [25]. In all, these studies further consolidate the concept that autophagy inhibition can be exploited to treat human cancers. Thus, pharmaceutical inhibition of autophagy emerges as a promising strategy in cancer therapy.

\section{Current autophagy inhibitors in clinical trials for cancer treatment}

Currently, there are about 32 ongoing clinical trials assessing the effect of autophagy manipulation on human cancer treatment, half of which are using chloroquine and hydroxychloroquine (the chloroquine derivative) (refer to reviews in [26-28]). A number of the latest phase I/II clinical trial reports evaluated the maximum tolerated dose, safety, preliminary activity, pharmacokinetics, and pharmacodynamics of hydroxychloroquine when combined with other therapies in treating glioblastoma, advanced solid tumor, and myeloma [29-33]. In one study, the combination of temsirolimus (mTOR inhibitor) and hydroxychloroquine improved the median progression-free survival in 13 melanoma patients to 3.5 months and increased the rate of stable disease in patients [32]. The beneficial effect of this combination was also observed in another phase I trial study conducted by the same group [33]. In another study, the combination of bortezomib (proteasome inhibitor) and hydroxychloroquine showed a high rate of partial response and stable disease in patients with relapsed/refractory myeloma [31]. Whereas, a phase I/II trial of hydroxychloroquine in conjunction with radiation therapy and concurrent and adjuvant temozolomide in patients with newly diagnosed glioblastoma multiforme led to no significant improvement in overall survival, which could be due to inconsistent autophagy inhibition in patients treated with this regimen [29]. These clinical trial studies indicate that autophagy inhibition with chloroquine/hydroxychloroquine treatment is achievable in patients and represents a potentially useful strategy for improving outcomes in cancer therapy. On the other hand, they also suggest the need to develop other compounds that can induce more consistent autophagy inhibition than chloroquine/ hydroxychloroquine in certain tumors.

Hydroxychloroquine/chloroquine inhibits autophagy by entering the lysosomes (lysosomotropic) and changing the acidity through chelating protons. As a result, the finishing step in autophagy that requires acidic lysosomes for degradation is blocked. In preclinical trials, the effect of chloroquine and hydroxychloroquine on tumorigenesis has been extensively investigated in mouse cancer models, including genetic and xenograft models (summarized in Table 2). As mentioned above, pancreatic cancers and Krasdriven lung cancers are highly dependent on autophagy for tumorigenic development, whereas other types of cancers might only use autophagy as a cell survival mechanism when stressed. This notion suggests a promising avenue in treating certain pancreatic and lung cancers that are notoriously refractory to pharmaceutical intervention. Two studies from Kimmelman's group demonstrated that chloroquine was able to suppress PDAC tumor growth in xenograft mouse models, irrespective of p53 status [34,22]. This is in contrast to studies from Ryan's group that showed that chloroquine accelerated PDAC development in p53 null mice instead of suppressing it [19], suggesting that the anti-tumor effects of chloroquine are p53 dependent. Notably, different p53-deficient mouse models were used by these two groups. Ryan's group used a mouse model of embryonic homologous deletion of p53, while Kimmelman's group used a loss of heterozygosity mouse model of p53 (closer to human tumors). Other than that, it remains unclear what causes the discrepancy.

In most cases of preclinical and clinical trials, chloroquine is used as a sensitizer/enhancer to chemotherapy and immunotherapy [35-47]. The rationale is that chemotherapy and immunotherapy can induce autophagy in tumor 
Table 2. Chloroquine (CQ)/hydroxychloroquine (HCQ) treatment in cancer mouse models

\begin{tabular}{|c|c|c|}
\hline Cancer mouse models & $\mathrm{CQ} / \mathrm{HCQ}$ treatment results & Ref. \\
\hline \multicolumn{3}{|l|}{ Genetic models } \\
\hline Atg $7^{+/+}, \mathrm{PdxI}-\mathrm{Cre}, \mathrm{LSL}-K$ ras $^{\mathrm{GI}} \mathrm{2D/+}, \mathrm{p} 53^{\text {flox/flox }}$ & Accelerate PDAC formation. & [19] \\
\hline LSL-Kras ${ }^{G / 2 D}, p 53^{f l o x /+}$ & Enhance animal survival. & [22] \\
\hline Eu-myc (a mouse model of Burkitt lymphoma) & Suppress myc-induced lymphomagenesis. & [85] \\
\hline $\operatorname{Atm}^{-1-}$ (a mouse model of ataxia telangiectasia) & Suppress spontaneous lymphoma development. & [85] \\
\hline$p 53^{-F_{-}^{-}}$ & Show no impact on lymphoma development. & [85] \\
\hline$p 53^{-\alpha}$ & Prevent carcinogen-induced mammary cancer in a p53-dependent manner. & [86] \\
\hline p53 ${ }^{K I / K I}$, Retro-myc & $\begin{array}{l}\text { Slow down lymphoma growth modestly and show no effect on tumor regression; delay } \\
\text { tumor recurrence with activation of } \mathrm{p} 53 \text {; enhance tumor regression and inhibit tumor } \\
\text { recurrence after alkylating drug therapy. }\end{array}$ & [87] \\
\hline \multicolumn{3}{|c|}{ (2) } \\
\hline 8988T cells (PDAC) & Promote tumor regression and enhance animal survival. & [22] \\
\hline Patient-derived pancreatic tumor cells & Inhibit xenograft tumor growth, irrespective of $p 53$ status. & [34] \\
\hline U87MG cells (human glioblastoma) & Suppress glioma growth. & [88] \\
\hline MDA-MB-23I cells (mammary carcinoma) & $\begin{array}{l}\text { The combination of CQ and panobinostat (pan-HDAC inhibitor) shows a significant } \\
\text { advantage over CQ or panobinostat alone in repressing tumor growth and prolonging } \\
\text { animal survival. }\end{array}$ & [35] \\
\hline HT29 cells (human colon carcinoma) & Sensitize mouse colon cancers to antiangiogenic and cytotoxic therapy. & [36] \\
\hline JIMT-I cells (human mammary carcinoma) & $\begin{array}{l}\text { Reduce tumor growth and sensitize trastuzumab-refractory xenograft tumors to } \\
\text { trastuzumab (monoclonal antibody). }\end{array}$ & [37] \\
\hline U25 I cells (human glioblastoma) & $\begin{array}{l}\text { The combination of CQ and ZD6474 (tyrosine kinase inhibitor) shows a significant } \\
\text { advantage over CQ or ZD } 6474 \text { alone in reducing tumor growth. }\end{array}$ & [38] \\
\hline U87MG cells (human glioblastoma) & $\begin{array}{l}\text { The combination of CQ and bevacizumab (VEGF-neutralizing antibody) shows a } \\
\text { significant advantage over bevacizumab alone in reducing tumor growth. }\end{array}$ & [39] \\
\hline SKBR-3 cells (mammary carcinoma) & $\begin{array}{l}\text { Potentiate chemotherapy using VN/I2-I (a bile acid metabolism blocking agent) in } \\
\text { reducing tumor growth. }\end{array}$ & [40] \\
\hline PC-3 cells (human prostate cancer) & $\begin{array}{l}\text { The combination of CQ and ABT-737 (anti-apoptotic mimetic) shows a significant } \\
\text { advantage over CQ or ABT-737 alone in repressing tumor growth. }\end{array}$ & [4I] \\
\hline Huh7 cells (human hepatoma) & Sensitize hepatoma to sorafenib (kinase inhibitor). & [42] \\
\hline SMMC-772I cells (hepatocarcinoma) & Potentiate chemotherapy using cisplatin or 5 -FU in inhibiting hepatocarcinoma growth. & [43] \\
\hline Huh7 cells (human hepatoma) & Enhance chemotherapy using oxaliplatin in inhibiting tumor growth. & [44] \\
\hline MHCC97-L cells (hepatocarcinoma) & Enhance chemotherapy using sorafenib in inhibiting tumor growth. & [45] \\
\hline $\begin{array}{l}\text { BxPC-3 cells (human primary pancreatic } \\
\text { adenocarcinoma) }\end{array}$ & $\begin{array}{l}\text { The combination of CQ and XL765 (PI3K/mTOR inhibitor) shows a significant advantage } \\
\text { over CQ or XL765 alone in repressing tumor growth. }\end{array}$ & [46] \\
\hline SCLC cells (lung cancer) & $\begin{array}{l}\text { The combination of } \mathrm{CQ} \text { and } \mathrm{ABT}-737 \text { (Bcl-2 inhibitor) shows no advantage over } \\
\mathrm{ABT}-737 \text { alone in reducing tumor growth. }\end{array}$ & [48] \\
\hline NSCLC cells (lung cancer) & $\begin{array}{l}\text { The combination of } \mathrm{HCQ} \text { and erlotinib (EFGR inhibitor) shows no advantage over } \\
\text { erlotinib alone in reducing tumor growth. }\end{array}$ & [49] \\
\hline $\begin{array}{l}\text { TLR9 siRNA MDA-MB-23I cells (mammary } \\
\text { carcinoma) }\end{array}$ & Fail to prevent tumor growth. & [89] \\
\hline colon 26 cells (colorectal cancer) & $\begin{array}{l}\text { The combination of } \mathrm{CQ} \text { and } 5 \text {-FU shows a significant advantage over 5-FU alone in } \\
\text { inhibiting tumor growth. }\end{array}$ & [90] \\
\hline MC38 cells (a mouse model of hepatic metastasis) & Enhance IL-2 in inhibiting tumor growth and prolonging animal survival. & [91] \\
\hline 4TI cells (mouse mammary carcinoma) & Inhibit growth and metastasis of implanted tumor cells, and enhance animal survival. & [92] \\
\hline PC-3 cells (human prostate cancer) & Enhance saracatinib (Src kinase inhibitor) in repressing tumor growth. & [47] \\
\hline HCT8 cells (human colon cancer) & $\begin{array}{l}\text { The combination of CQ and SAHA (also named vorinostat, HDAC inhibitor) shows a } \\
\text { stronger effect than } \mathrm{CQ} \text { or SAHA alone in reducing tumor burden. }\end{array}$ & [93] \\
\hline
\end{tabular}

Abbreviations: PDAC, pancreatic ductal adenocarcinoma; ATM, ataxia-telangiectasia mutated; SCLC, small cell lung cancer; TLR9, toll like receptor 9; NSCLC, non-small cell lung cancer; 5-FU, 5-fluorouracil.

cells, which in turn is used by tumor cells as a survival mechanism to resist pharmaceutical invention. As such, blocking of autophagy with chloroquine produces a synergistic effect and increases drug cytotoxicity. This combined treatment shows a significant preclinical effect on several types of cancers, but marginal effects on many others (Table 2) [48,49], suggesting that the chloroquine effect is likely tissue- or tumor-type-dependent.

There are concerns about chloroquine/hydroxychloroquine treatment. Inconsistent inhibition of autophagy in humans is a major issue for its clinical trials $[46,50,51]$. What's more, prolonged chloroquine treatment might promote autophagosome biogenesis $[52,53]$. From the perspective of cell biology, it is believed that chloroquine achieves most of its pharmaceutical effects through inhibiting lysosomal functions. Lysosomes are involved not only in autophagy, but also in endosomal trafficking and antibody presentation. As a result, chloroquine also interferes with endosomal signaling and immune response [54,55]. In addition, chloroquine has non-lysosomal targets. For example, chloroquine acts on endosomal Notch1 trafficking and signaling to normalize tumor vasculature in an autophagyindependent manner [56]. Additionally, chloroquine 
causes intracellular acidification [57]. Chloroquine binds to thiamine transporters or enters other acidic organelles $[21,58]$. Such promiscuous properties of chloroquine may account for its adverse effects during therapy, including retinopathy and immunosuppression $[59,60]$, which highlights the need for the development of more specific inhibitors targeting only autophagy.

\section{Future directions}

It is commonly speculated that new therapeutic approaches might be developed by targeting the autophagic pathway, which consists of a number of steps including initiation, membrane nucleation, membrane elongation, membrane closure, membrane fusion, and lysosomal degradation (Figure 2) [61].

Figure 2. Potential drug targets in the autophagic pathway to treat human cancers

\begin{tabular}{ccc}
\hline Autophagic process & Potential drug targets & $\begin{array}{c}\text { Chemicals in experimental or } \\
\text { clinical use }\end{array}$ \\
$\begin{array}{c}\text { Autophagy } \\
\text { induction }\end{array}$ & TORC1; ULK1 complex & $\begin{array}{l}\text { rapamycin, everolimus, } \\
\text { temsirolimus, ridaforolimus, } \\
\text { WYE-125132 }\end{array}$ \\
$\begin{array}{c}\text { Membrane } \\
\text { nucleation }\end{array}$ & Class III PI3K complex & $\begin{array}{l}\text { 3-methyladenine, wortmanin, } \\
\text { PIK-III, SAR405, Spautin-1 }\end{array}$
\end{tabular}

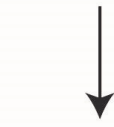

Membrane elongation

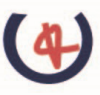<smiles>C=CC</smiles>

Membrane

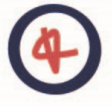

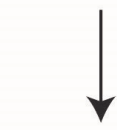

Membrane
fusion

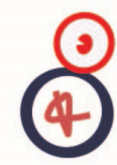

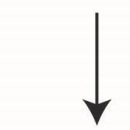

Lysosomal degradation

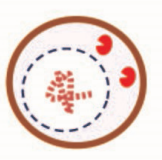

pH; proton pump

ubiquitination-like and deubiquitination-like enzymes

deubiquitination-like enzyme?

ATG4B inhibitors

membrane tethering factors; SNARE complex; SNARE associated proteins

chloroquine, hydroxychloroquine, bafilomycin $\mathrm{A} 1$, Lys05 
As discussed above, current autophagy inhibitors, such as chloroquine, hydroxychloroquine, and bafilomycin A1, mainly inhibit lysosomal functions. Recently the lipid kinase Vps34, which is essential for autophagy, also emerged as a target of pharmaceutical interest. While a number of inhibitors are known to effectively inhibit Vps34 activity, including 3-methyladenine and wortmannin, their clinical application has limitations, because they also inhibit Class I and II lipid kinases and other protein kinases [21]. Most recently, however, two structurally distinct Vps34 inhibitors, which possess higher selectivity compared with existing inhibitors, have been reported [62,63]. PIK-III and SAR405 were discovered and developed in large-scale screens of chemicals that inhibit Vps34 activity in vitro and PI3P production in vivo, respectively. Interestingly, both inhibitors are bound within the ATP binding cleft but adopt different binding modes to interact with surrounding residues. These unique contacts confer high specificity to new inhibitors, because they are not present in other similar kinases, including class I PI3K and mTOR. While these findings represent a step forward towards the development of more specific autophagy inhibitors, it should be noted that Vps34 is also involved in the endosomal signaling pathway by forming the endosomal Class III PI3K complex (Vps34/p150/BECN1/ UVRAG/RUBICON) in mammals [64-70]. Inhibition of Vps34 activity will affect both autophagy and endosomal trafficking. Vps34 activity in autophagy is tightly controlled by assembling the autophagy specific class III PI3K subcomplex (Vps34/p150/BECN1/ATG14) $[66,67,71-74]$. Specific inhibition of Vps34 activity in the complex form might differentiate the effect on autophagy or endocytosis. In this regard, a large-scale screen of chemicals targeting activity of Vps34/p150/ BECN1/ATG14 instead of Vps34 alone might be more appropriate. New inhibitors might be identified through inhibiting Vps34 activity in an allosteric manner and thus guarantee high selectivity.

The membrane fusion process in autophagy can also be exploited to develop more autophagy specific inhibitors. The SNARE proteins (Soluble N-ethylmaleimidesensitive factor Attachment protein REceptors) mediate vesicular fusion events inside the cells. A unique set of autophagic SNARE proteins Syntaxin17, SNAP29, and VAMP8 are essential for the fusion between autophagosomes and lysosomes [75,76]. Recently, we have been able to reconstitute their fusogenic activity in intro (unpublished data, Zhong et al.), and this fusion activity is likely precisely regulated by multiple autophagy specific protein factors. The reconstituted fusion activity may also be exploited to screen for autophagy inhibitors.
Even if highly specific autophagy inhibitors are developed, one should be cautious about their potential "sideeffects" when used as a cancer therapy. Acute ablation of autophagy leads to animal death caused by infection, diabetes, and neurodegeneration, as well as muscle dystrophy and reduced fat storage [18]. These unwanted effects might impede the enthusiasm for developing drugs targeting autophagy. On the other hand, there is considerable interest in developing autophagy activators to battle against infectious diseases and neurodegeneration, in which autophagy activation should alleviate the symptoms $[77,78]$.

In closing, given the broad involvement of autophagy in defense against infection, neurodegenerative disorders, diabetes, cancer and aging, reagents that specifically regulate autophagy will have wide therapeutic applications. Most importantly, our understanding of autophagy in cancer will finally give us an advantage in the war with cancer.

\section{Abbreviations}

PDAC, pancreatic ductal adenocarcinoma; ROS, reactive oxygen species.

\section{Disclosures}

The authors declare that they have no disclosures.

\section{References}

I. Liang XH, Jackson S, Seaman M, Brown K, Kempkes B, Hibshoosh H, Levine $B$ : Induction of autophagy and inhibition of tumorigenesis by beclin I. Nature 1999, 402:672-6.

\section{FlOOOPrime} RECOMMENDED

2. Aita VM, Liang $X H$, Murty VV, Pincus DL, Yu W, Cayanis E, Kalachikov S, Gilliam TC, Levine B: Cloning and genomic organization of beclin I, a candidate tumor suppressor gene on chromosome I7q2 I. Genomics 1999, 59:59-65.

3. Laddha SV, Ganesan S, Chan CS, White E: Mutational landscape of the essential autophagy gene BECNI in human cancers. Mol Cancer Res 2014, 12:485-90.

FlOOOPrime

RECOMMENDED

4. Easton DF: How many more breast cancer predisposition genes are there? Breast Cancer Res 1999, I:I4-7.

5. Campeau PM, Foulkes WD, Tischkowitz MD: Hereditary breast cancer: new genetic developments, new therapeutic avenues. Hum Genet 2008, I 24:31-42.

6. Drost RM, Jonkers J: Preclinical mouse models for BRCAIassociated breast cancer. Br J Cancer 2009, I 0 I:I65 I-7.

$$
\begin{aligned}
& \text { FlOOOPrime } \\
& \text { RECOMMENDED }
\end{aligned}
$$

7. Qu X, Yu J, Bhagat G, Furuya N, Hibshoosh H, Troxel A, Rosen J, Eskelinen E, Mizushima N, Ohsumi Y, Cattoretti G, Levine B: Promotion of tumorigenesis by heterozygous disruption of the beclin I autophagy gene. Journal Clin Invest 2003, I | 2: | 809-20. 
8. Yue Z, Jin S, Yang C, Levine AJ, Heintz N: Beclin I, an autophagy gene essential for early embryonic development, is a haploinsufficient tumor suppressor. Proc Natl Acad Sci USA 2003, 100:15077-82.

\section{FlOOOPrime \\ RECOMMENDED}

9. Lebovitz $C B$, Bortnik SB, Gorski SM: Here, there be dragons: charting autophagy-related alterations in human tumors. Clin Cancer Res 2012, I8:1214-26.

10. Sato T, Nakashima A, Guo L, Coffman K, Tamanoi F: Single aminoacid changes that confer constitutive activation of mTOR are discovered in human cancer. Oncogene 2010, 29:2746-52.

\section{FlOOOPrime} RECOMMENDED

II. Hardt M, Chantaravisoot N, Tamanoi F: Activating mutations of TOR (target of rapamycin). Genes Cells 20II, I6:14I-5I.

12. An $\mathrm{CH}$, Kim MS, Yoo NJ, Park SW, Lee SH: Mutational and expressional analyses of ATG5, an autophagy-related gene, in gastrointestinal cancers. Pathol Res Pract 20I I, 207:433-7.

13. Kang MR, Kim MS, Oh JE, Kim YR, Song SY, Kim SS, Ahn CH, Yoo NJ, Lee $\mathrm{SH}$ : Frameshift mutations of autophagy-related genes ATG2B, ATG5, ATG9B and ATG 12 in gastric and colorectal cancers with microsatellite instability. J Pathol 2009, 217:702-6.

\section{FlOOOPrime}

\section{RECOMMENDED}

14. Qu X, Zou Z, Sun Q, Luby-Phelps K, Cheng P, Hogan RN, Gilpin C, Levine B: Autophagy gene-dependent clearance of apoptotic cells during embryonic development. Cell 2007, I 28:93 I-46.

\section{FlOOOPrime \\ RECOMMENDED}

15. Kuma A, Hatano M, Matsui M, Yamamoto A, Nakaya H, Yoshimori T, Ohsumi $Y$, Tokuhisa T, Mizushima N: The role of autophagy during the early neonatal starvation period. Nature 2004, 432: 1032-6.

\section{FlOOOPrime \\ RECOMMENDED}

16. Komatsu M, Waguri S, Ueno T, Iwata J, Murata S, Tanida I, Ezaki J, Mizushima N, Ohsumi Y, Uchiyama Y, Kominami E, Tanaka K, Chiba T: Impairment of starvation-induced and constitutive autophagy in Atg7-deficient mice. J Cell Biol 2005, 169:425-34.

\section{FlOOOPrime}

17. Takamura A, Komatsu M, Hara T, Sakamoto A, Kishi C, Waguri S, Eishi Y, Hino O, Tanaka K, Mizushima N: Autophagy-deficient mice develop multiple liver tumors. Genes Dev 20I I, 25:795-800.

\section{FlOOOPrime} RECOMMENDE

18. Rosenfeldt MT, O'Prey J, Morton JP, Nixon C, MacKay G, Mrowinska A, Au A, Rai TS, Zheng L, Ridgway R, Adams PD, Anderson KI, Gottlieb E, Sansom OJ, Ryan KM: p53 status determines the role of autophagy in pancreatic tumour development. Nature 2013, 504:296-300.

\section{FlOOOPrime \\ RECOMMENDED}

19. Rao S, Tortola L, Perlot T, Wirnsberger G, Novatchkova M, Nitsch R, Sykacek P, Frank L, Schramek D, Komnenovic V, Sigl V, Aumayr K, Schmauss G, Fellner N, Handschuh S, Glösmann M, Pasierbek P, Schlederer M, Resch GP, Ma Y, Yang H, Popper H, Kenner L, Kroemer G, Penninger JM: A dual role for autophagy in a murine model of lung cancer. Nat Commun 20 I4, 5:3056.

\section{FlOOOPrime \\ RECOMMENDED}

20. Vinod V, Padmakrishnan CJ, Vijayan B, Gopala S: 'How can I halt thee?' The puzzles involved in autophagic inhibition. Pharmacol Res 2014, 82:I-8.
21. Yang S, Wang X, Contino G, Liesa M, Sahin E, Ying H, Bause A, Li Y Stommel JM, Dell'antonio G, Mautner J, Tonon G, Haigis M, Shirihai OS, Doglioni C, Bardeesy N, Kimmelman AC: Pancreatic cancers require autophagy for tumor growth. Genes Dev 20II, 25:717-29.

\section{FlOOOPrime}

22. Guo JY, Karsli-Uzunbas G, Mathew R, Aisner SC, Kamphorst JJ, Strohecker AM, Chen G, Price S, Lu W, Teng X, Snyder E, Santanam U, Dipaola RS, Jacks T, Rabinowitz JD, White E: Autophagy suppresses progression of K-ras-induced lung tumors to oncocytomas and maintains lipid homeostasis. Genes Dev 2013, 27:|447-6I.

\section{FlOOOPrime RECOMMENDED}

23. Strohecker AM, Guo JY, Karsli-Uzunbas G, Price SM, Chen G], Mathew R, McMahon M, White E: Autophagy sustains mitochondrial glutamine metabolism and growth of BrafV600E-driven lung tumors. Cancer Discov 2013, 3:1272-85.

\section{FlOOOPrime}

24. Wei H, Wei S, Gan B, Peng X, Zou W, Guan J: Suppression of autophagy by FIP200 deletion inhibits mammary tumorigenesis. Genes Dev 2011, 25:1510-27.

\section{FlOOOPrime}

25. Solomon VR, Lee $H$ : Chloroquine and its analogs: a new promise of an old drug for effective and safe cancer therapies. Eur J Pharmacol 2009, 625:220-33.

26. Ávalos Y, Canales J, Bravo-Sagua R, Criollo A, Lavandero S, Quest, Andrew FG: Tumor suppression and promotion by autophagy. BioMed Res Int 2014, 20 I 4:603980.

27. Jiang P, Mizushima N: Autophagy and human diseases. Cell Res 2014, 24:69-79.

28. Rosenfeld MR, Ye X, Supko JG, Desideri S, Grossman SA, Brem S, Mikkelson T, Wang D, Chang YC, Hu J, McAfee Q, Fisher J, Troxel AB, Piao S, Heitjan DF, Tan K, Pontiggia L, O'Dwyer PJ, Davis LE, Amaravadi RK: A phase I/II trial of hydroxychloroquine in conjunction with radiation therapy and concurrent and adjuvant temozolomide in patients with newly diagnosed glioblastoma multiforme. Autophagy 2014, 10:1359-68.

29. Mahalingam D, Mita M, Sarantopoulos J, Wood L, Amaravadi RK, Davis LE, Mita AC, Curiel TJ, Espitia CM, Nawrocki ST, Giles F], Carew JS: Combined autophagy and HDAC inhibition: a phase $I$ safety, tolerability, pharmacokinetic, and pharmacodynamic analysis of hydroxychloroquine in combination with the HDAC inhibitor vorinostat in patients with advanced solid tumors. Autophagy 2014, 10:1403-14.

30. Vogl DT, Stadtmauer EA, Tan K, Heitjan DF, Davis LE, Pontiggia L, Rangwala R, Piao S, Chang YC, Scott EC, Paul TM, Nichols CW, Porter DL, Kaplan J, Mallon G, Bradner JE, Amaravadi RK: Combined autophagy and proteasome inhibition: a phase I trial of hydroxychloroquine and bortezomib in patients with relapsed/refractory myeloma. Autophagy 2014, 10:1380-90.

\section{FlOOOPrime}

31. Rangwala R, Chang YC, Hu J, Algazy KM, Evans TL, Fecher LA Schuchter LM, Torigian DA, Panosian JT, Troxel AB, Tan K, Heitjan DF, DeMichele AM, Vaughn DJ, Redlinger M, Alavi A, Kaiser J, Pontiggia L, Davis LE, O'Dwyer PJ, Amaravadi RK: Combined MTOR and autophagy inhibition: phase I trial of hydroxychloroquine and temsirolimus in patients with advanced solid tumors and melanoma. Autophagy 2014, 10:1391-402

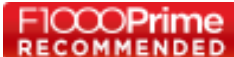

32. Rangwala R, Leone R, Chang YC, Fecher LA, Schuchter LM, Kramer A Tan K, Heitjan DF, Rodgers G, Gallagher M, Piao S, Troxel AB, Evans TL, DeMichele AM, Nathanson KL, O'Dwyer PJ, Kaiser J, Pontiggia L, Davis LE, Amaravadi RK: Phase I trial of hydroxychloroquine with dose-intense temozolomide in patients 
with advanced solid tumors and melanoma. Autophagy 2014, 10:1369-79.

\section{FlOOOPrime}

33. Yang A, Rajeshkumar NV, Wang X, Yabuuchi S, Alexander BM, Chu GC, Von Hoff, Daniel D, Maitra A, Kimmelman AC: Autophagy is critical for pancreatic tumor growth and progression in tumors with p53 alterations. Cancer Discov 20I4, 4:905-I3.

\section{FlOOOPrime}

\section{RECOMMENDED}

34. Rao R, Balusu R, Fiskus W, Mudunuru U, Venkannagari S, Chauhan L, Smith JE, Hembruff SL, Ha K, Atadja P, Bhalla KN: Combination of pan-histone deacetylase inhibitor and autophagy inhibitor exerts superior efficacy against triple-negative human breast cancer cells. Mol Cancer Ther 2012, II:973-83.

35. Selvakumaran M, Amaravadi RK, Vasilevskaya IA, O'Dwyer PJ: Autophagy inhibition sensitizes colon cancer cells to antiangiogenic and cytotoxic therapy. Clin Cancer Res 2013, 19:2995-3007.

36. Cufí S, Vazquez-Martin A, Oliveras-Ferraros C, Corominas-Faja B, Cuyàs E, López-Bonet E, Martin-Castillo B, Joven J, Menendez JA: The anti-malarial chloroquine overcomes primary resistance and restores sensitivity to trastuzumab in HER2-positive breast cancer. Sci Rep 2013, 3:2469.

37. Shen J, Zheng H, Ruan J, Fang W, Li A, Tian G, Niu X, Luo S, Zhao P: Autophagy inhibition induces enhanced proapoptotic effects of ZD6474 in glioblastoma. Br J Cancer 2013, 109:164-71.

38. Hu Y, DeLay M, Jahangiri A, Molinaro AM, Rose SD, Carbonell WS, Aghi MK: Hypoxia-induced autophagy promotes tumor cell survival and adaptation to antiangiogenic treatment in glioblastoma. Cancer Res 2012, 72:1773-83.

39. Godbole AM, Purushottamachar P, Martin MS, Daskalakis C, Njar Vincent CO: Autophagy inhibition synergistically enhances anticancer efficacy of RAMBA, VN/I 2-I in SKBR-3 cells, and tumor xenografts. Mol Cancer Ther 2012, I I:898-908.

40. Saleem A, Dvorzhinski D, Santanam U, Mathew R, Bray K, Stein M, White E, Dipaola RS: Effect of dual inhibition of apoptosis and autophagy in prostate cancer. Prostate 2012, 72:1374-8I.

4I. Shimizu S, Takehara T, Hikita H, Kodama T, Tsunematsu H, Miyagi T, Hosui A, Ishida H, Tatsumi T, Kanto T, Hiramatsu N, Fujita N, Yoshimori T, Hayashi N: Inhibition of autophagy potentiates the antitumor effect of the multikinase inhibitor sorafenib in hepatocellular carcinoma. Int J Cancer 2012, 131:548-57.

42. Guo X, Li D, Hu F, Song J, Zhang S, Deng W, Sun K, Zhao Q, Xie X, Song $Y$, Wu M, Wei L: Targeting autophagy potentiates chemotherapy-induced apoptosis and proliferation inhibition in hepatocarcinoma cells. Cancer Lett 2012, 320:171-9.

43. Ding Z, Hui B, Shi Y, Zhou J, Peng Y, Gu C, Yang H, Shi G, Ke A, Wang $X$, Song K, Dai Z, Shen Y, Fan J: Autophagy activation in hepatocellular carcinoma contributes to the tolerance of oxaliplatin via reactive oxygen species modulation. Clin Cancer Res 20II, 17:6229-38.

44. Shi Y, Ding Z, Zhou J, Hui B, Shi G, Ke A, Wang X, Dai Z, Peng Y, Gu C, Qiu S, Fan J: Targeting autophagy enhances sorafenib lethality for hepatocellular carcinoma via ER stress-related apoptosis. Autophagy 2011, 7:1159-72.

45. Mirzoeva OK, Hann B, Hom YK, Debnath J, Aftab D, Shokat K, Korn WM: Autophagy suppression promotes apoptotic cell death in response to inhibition of the PI3K-mTOR pathway in pancreatic adenocarcinoma. J Mol Med (Berl) 20II, 89:877-89.

46. Wu Z, Chang P, Yang JC, Chu C, Wang L, Chen N, Ma A, Desai SJ, Lo SH, Evans CP, Lam KS, Kung H: Autophagy Blockade Sensitizes Prostate Cancer Cells towards Src Family Kinase Inhibitors. Genes Cancer 2010, I:40-9.

47. Zinn RL, Gardner EE, Dobromilskaya I, Murphy S, Marchionni L, Hann CL, Rudin CM: Combination treatment with ABT-737 and chloroquine in preclinical models of small cell lung cancer. Mol Cancer 2013, 12:16.

FIOOOPrime

48. Zou Y, Ling Y, Sironi J, Schwartz EL, Perez-Soler R, Piperdi B: The autophagy inhibitor chloroquine overcomes the innate resistance of wild-type EGFR non-small-cell lung cancer cells to erlotinib. J Thorac Oncol 2013, 8:693-702.

\section{FIOOOPrime}

49. McAfee Q, Zhang Z, Samanta A, Levi SM, Ma X, Piao S, Lynch JP, Uehara T, Sepulveda AR, Davis LE, Winkler JD, Amaravadi RK: Autophagy inhibitor Lys05 has single-agent antitumor activity and reproduces the phenotype of a genetic autophagy deficiency. Proc Natl Acad Sci USA 2012, 109:8253-8.

50. Bristol ML, Emery SM, Maycotte P, Thorburn A, Chakradeo S, Gewirtz DA: Autophagy inhibition for chemosensitization and radiosensitization in cancer: do the preclinical data support this therapeutic strategy? J Pharmacol Exp Ther 2013, 344:544-52.

51. Kimura N, Kumamoto T, Kawamura Y, Himeno T, Nakamura K, Ueyama H, Arakawa R: Expression of autophagy-associated genes in skeletal muscle: an experimental model of chloroquineinduced myopathy. Pathobiology 2007, 74:169-76.

\section{FlOOOPrime
RECOMMENDED}

52. Donohue E, Thomas A, Maurer N, Manisali I, Zeisser-Labouebe M, Zisman N, Anderson HJ, Ng, Sylvia SW, Webb M, Bally M, Roberge M: The autophagy inhibitor verteporfin moderately enhances the antitumor activity of gemcitabine in a pancreatic ductal adenocarcinoma model. J Cancer 2013, 4:585-96.

\section{FlOOOPrime}

RECOMMENDED

53. Rodriguez-Caruncho C, Bielsa Marsol I: Antimalarials in dermatology: mechanism of action, indications, and side effects. Actas Dermosifiliogr 2014, 105:243-52.

54. Thomé R, Lopes, Stefanie Costa Pinto, Costa, Fabio Trindade Maranhão, Verinaud L: Chloroquine: modes of action of an undervalued drug. Immunol Lett, 153:50-7.

55. Maes H, Kuchnio A, Peric A, Moens S, Nys K, Bock K de, Quaegebeur A, Schoors S, Georgiadou M, Wouters J, Vinckier S, Vankelecom H, Garmyn M, Vion A, Radtke F, Boulanger C, Gerhardt $H$, Dejana $E$, Dewerchin $M$, Ghesquière $B$, Annaert W, Agostinis $P$, Carmeliet $P$ : Tumor vessel normalization by chloroquine independent of autophagy. Cancer Cell 2014, 26:190-206.

56. Gottlieb RA, Nordberg J, Skowronski E, Babior BM: Apoptosis induced in Jurkat cells by several agents is preceded by intracellular acidification. Proc Natl Acad Sci USA 1996, 93:654-8.

57. Huang Z, Srinivasan S, Zhang J, Chen K, Li Y, Li W, Quiocho FA, Pan $X$ : Discovering thiamine transporters as targets of chloroquine using a novel functional genomics strategy. PLoS genetics 2012, 8: 1003083.

58. Costedoat-Chalumeau N, Dunogué B, Morel N, Le Guern V, Guettrot-Imbert G: Hydroxychloroquine: a multifaceted treatment in lupus. Presse Med 2014, 43:el67-80.

59. Townsend KN, Hughson, Luke RK, Schlie K, Poon VI, Westerback A, Lum JJ: Autophagy inhibition in cancer therapy: metabolic considerations for antitumor immunity. Immunol Rev 2012, 249:176-94.

60. Parzych KR, Klionsky DJ: An overview of autophagy: morphology, mechanism, and regulation. Antioxid Redox Signal 20I4, 20:460-73.

6I. Dowdle WE, Nyfeler B, Nagel J, Elling RA, Liu S, Triantafellow E, Menon S, Wang Z, Honda A, Pardee G, Cantwell J, Luu C, CornellaTaracido I, Harrington E, Fekkes P, Lei H, Fang Q, Digan ME, Burdick D, Powers AF, Helliwell SB, D'Aquin S, Bastien J, Wang H, Wiederschain D, Kuerth J, Bergman P, Schwalb D, Thomas J, Ugwonali S, et al:: Selective VPS34 inhibitor blocks autophagy 
and uncovers a role for NCOA4 in ferritin degradation and iron homeostasis in vivo. Nat Cell Biol 2014, 16:1069-79.

\section{FIOOOPrime}

62. Ronan B, Flamand O, Vescovi L, Dureuil C, Durand L, Fassy F, Bachelot M, Lamberton A, Mathieu M, Bertrand T, Marquette J, El-Ahmad Y, FilocheRomme B, Schio L, Garcia-Echeverria C, Goulaouic H, Pasquier B: A highly potent and selective Vps34 inhibitor alters vesicle trafficking and autophagy. Nature Chem Biol 2014, I0:1013-9.

\section{FIOOOPrime
RECOMMENDED}

63. Liang $\mathrm{C}$, Feng $\mathrm{P}, \mathrm{Ku} \mathrm{B}$, Dotan I, Canaani D, Oh B, Jung JU: Autophagic and tumour suppressor activity of a novel Beclin I-binding protein UVRAG. Nat Cell Biol 2006, 8:688-99.

\section{FlOOOPrime
RECOMMENDED}

64. Liang C, Lee J, Inn K, Gack MU, Li Q, Roberts EA, Vergne I, Deretic V, Feng $\mathrm{P}$, Akazawa $\mathrm{C}$, Jung JU: Beclin I-binding UVRAG targets the class C Vps complex to coordinate autophagosome maturation and endocytic trafficking. Nat Cell Biol 2008, I0:776-87.

\section{FlOOOPrime} RECOMMENDED

65. Matsunaga K, Saitoh T, Tabata K, Omori H, Satoh T, Kurotori N, Maejima I, Shirahama-Noda K, Ichimura T, Isobe T, Akira S, Noda T, Yoshimori T: Two Beclin I-binding proteins, Atg I4L and Rubicon, reciprocally regulate autophagy at different stages. Nat Cell Biol 2009, I I:385-96.

\section{FlOOOPrime

RECOMMENDED

66. Zhong Y, Wang QJ, Li X, Yan Y, Backer JM, Chait BT, Heintz N, Yue Z: Distinct regulation of autophagic activity by Atg I 4L and Rubicon associated with Beclin I-phosphatidylinositol-3kinase complex. Nat Cell Biol 2009, I I:468-76.

67. Sun Q, Westphal W, Wong KN, Tan I, Zhong Q: Rubicon controls endosome maturation as a Rab7 effector. Proc Natl Acad Sci USA 2010, 107:19338-43.

68. Sun Q, Zhang J, Fan W, Wong KN, Ding X, Chen S, Zhong Q: The RUN domain of rubicon is important for hVps34 binding, lipid kinase inhibition, and autophagy suppression. J Biol Chem 20II, 286: I85-91.

69. Tabata K, Matsunaga K, Sakane A, Sasaki T, Noda T, Yoshimori T: Rubicon and PLEKHMI negatively regulate the endocyticl autophagic pathway via a novel Rab7-binding domain. Mol Bio Cell 2010, 21:4162-72.

70. Funderburk SF, Wang QJ, Yue Z: The Beclin I-VPS34 complexat the crossroads of autophagy and beyond. Trends Cell Biol 2010, 20:355-62

7I. Sun Q, Fan W, Chen K, Ding X, Chen S, Zhong Q: Identification of Barkor as a mammalian autophagy-specific factor for Beclin I and class III phosphatidylinositol 3-kinase. Proc Natl Acad Sci USA 2008, 105:19211-6.

72. Itakura E, Kishi C, Inoue K, Mizushima N: Beclin I forms two distinct phosphatidylinositol 3-kinase complexes with mammalian Atg I 4 and UVRAG. Mol Biol Cell 2008, 19:5360-72.

73. Kim J, Kim YC, Fang C, Russell RC, Kim JH, Fan W, Liu R, Zhong Q, Guan K: Differential regulation of distinct Vps34 complexes by AMPK in nutrient stress and autophagy. Cell 2013, I 52:290-303.

\section{FlOOOPrime RECOMMENDED}

74. Itakura E, Kishi-Itakura C, Mizushima N: The hairpin-type tailanchored SNARE syntaxin I 7 targets to autophagosomes for fusion with endosomes/lysosomes. Cell 20I2, I5 I:I256-69.

\section{FlOOOPrime}

\section{RECOMMENDED}

75. Takáts S, Nagy P, Varga Á, Pircs K, Kárpáti M, Varga K, Kovács AL, Heged冈s K, Juhász G: Autophagosomal Syntaxin I 7-dependent
Iysosomal degradation maintains neuronal function in Drosophila. J Cell Biol 2013, 201:531-9.

\section{FIOOOPrime}

76. Karsli-Uzunbas G, Guo JY, Price S, Teng X, Laddha SV, Khor S, Kalaany NY, Jacks T, Chan CS, Rabinowitz JD, White E: Autophagy is required for glucose homeostasis and lung tumor maintenance. Cancer Discov 2014, 4:9|4-27.

\section{FlOOOPRIME
RECOMMENDED}

77. Shoji-Kawata S, Sumpter R, Leveno M, Campbell GR, Zou Z, Kinch L, Wilkins $A D$, Sun $Q$, Pallauf $K$, MacDuff D, Huerta $C$, Virgin HW, Helms JB, Eerland R, Tooze SA, Xavier R, Lenschow DJ, Yamamoto A, King D, Lichtarge O, Grishin NV, Spector SA, Kaloyanova DV, Levine B: Identification of a candidate therapeutic autophagyinducing peptide. Nature 2013, 494:20I-6.

\section{FIOOOPrime
RECOMMENDED}

78. Liu Y, Shoji-Kawata S, Sumpter RM, Wei Y, Ginet V, Zhang L, Posner B, Tran KA, Green DR, Xavier RJ, Shaw SY, Clarke, Peter GH, Puyal J, Levine B: Autosis is a Na+,K+-ATPase-regulated form of cell death triggered by autophagy-inducing peptides, starvation, and hypoxia-ischemia. Proc Natl Acad Sci USA 2013, | | 0:20364-7|

79. Huo Y, Cai H, Teplova I, Bowman-Colin C, Chen G, Price S, Barnard N, Ganesan S, Karantza V, White E, Xia B: Autophagy opposes p53-mediated tumor barrier to facilitate tumorigenesis in a model of PALB2-associated hereditary breast cancer. Cancer Discov 2013, 3:894-907.

80. Valentin-Vega YA, Maclean KH, Tait-Mulder J, Milasta S, Steeves M, Dorsey FC, Cleveland JL, Green DR, Kastan MB: Mitochondrial dysfunction in ataxia-telangiectasia. Blood 20I2, I I 9: |490-500.

\section{FIOOOPRIM
RECOMMENDED}

8I. Lozy F, Cai-McRae X, Teplova I, Price S, Reddy A, Bhanot G, Ganesan S, Vazquez A, Karantza V: ERBB2 overexpression suppresses stress-induced autophagy and renders ERBB2induced mammary tumorigenesis independent of monoallelic Becn I loss. Autophagy 2014, 10:662-76.

82. Takahashi Y, Coppola D, Matsushita N, Cualing HD, Sun M, Sato Y, Liang C, Jung JU, Cheng JQ, Mulé J], Pledger WJ, Wang H: Bif-I interacts with Beclin I through UVRAG and regulates autophagy and tumorigenesis. Nat Cell Biol 2007, 9:| |42-5 I.

\section{FlOOOPrime} RECOMMENDED

83. Takahashi Y, Hori T, Cooper TK, Liao J, Desai N, Serfass JM, Young MM, Park S, Izu Y, Wang $\mathrm{H}$ : Bif-I haploinsufficiency promotes chromosomal instability and accelerates Mycdriven Iymphomagenesis via suppression of mitophagy. Blood 2013, I 2 I: 1622-32.

84. Mariño G, Salvador-Montoliu N, Fueyo A, Knecht E, Mizushima N, López-Otín C: Tissue-specific autophagy alterations and increased tumorigenesis in mice deficient in Atg4C/autophagin-3. J Biol Chem 2007, 282: I8573-83.

85. Maclean KH, Dorsey FC, Cleveland JL, Kastan MB: Targeting lysosomal degradation induces p53-dependent cell death and prevents cancer in mouse models of lymphomagenesis. J Clin Invest 2008, I | 8:79-88.

86. Loehberg CR, Thompson T, Kastan MB, Maclean KH, Edwards DG, Kittrell FS, Medina D, Conneely OM, O'Malley BW: Ataxia telangiectasia-mutated and p53 are potential mediators of chloroquine-induced resistance to mammary carcinogenesis. Cancer Res 2007, 67:12026-33

87. Amaravadi RK, Yu D, Lum JJ, Bui T, Christophorou MA, Evan GI, Thomas-Tikhonenko A, Thompson CB: Autophagy inhibition 
enhances therapy-induced apoptosis in a Myc-induced model of lymphoma. J Clin Invest 2007, II 7:326-36.

\section{FlOOOPrime}

88. Kim EL, Wüstenberg R, Rübsam A, Schmitz-Salue C, Warnecke G, Bücker E, Pettkus N, Speidel D, Rohde V, Schulz-Schaeffer W, Deppert W, Giese A: Chloroquine activates the p53 pathway and induces apoptosis in human glioma cells. Neuro-oncology 2010, I 2:389-400.

89. Tuomela J, Sandholm J, Kauppila JH, Lehenkari P, Harris KW, Selander KS: Chloroquine has tumor-inhibitory and tumorpromoting effects in triple-negative breast cancer. Oncol Lett 20I3, 6:1665-72.

90. Sasaki K, Tsuno NH, Sunami E, Kawai K, Hongo K, Hiyoshi M, Kaneko M, Murono K, Tada N, Nirei T, Takahashi K, Kitayama J: Resistance of colon cancer to 5 -fluorouracil may be overcome by combination with chloroquine, an in vivo study. Anticancer Drugs 2012, 23:675-82.

91. Liang X, De Vera, Michael E, Buchser WJ, Romo de Vivar Chavez, Antonio, Loughran P, Beer Stolz D, Basse P, Wang T, van Houten B, Zeh HJ, Lotze MT: Inhibiting systemic autophagy during interleukin 2 immunotherapy promotes long-term tumor regression. Cancer Res 2012, 72:279I-80I.

92. Jiang $P$, Zhao $Y$, Deng X, Mao Y, Shi W, Tang Q, Li Z, Zheng Y, Yang S, Wei $Y$ : Antitumor and antimetastatic activities of chloroquine diphosphate in a murine model of breast cancer. Biomed Pharmacother 2010, 64:609-14.

93. Carew JS, Medina EC, Esquivel JA, Mahalingam D, Swords R, Kelly K, Zhang H, Huang P, Mita AC, Mita MM, Giles FJ, Nawrocki ST: Autophagy inhibition enhances vorinostat-induced apoptosis via ubiquitinated protein accumulation. J Cell Mol Med 2010, 14:2448-59. 